\title{
PEMBUATAN OTAK-OTAK IKAN GABUS SEBAGAI ALTERNATIF MAKANAN SUMBER ALBUMIN
}

\author{
Dewi Hermawati Wahyuningsih \\ Sekolah Tinggi Pariwisata Sahid Surakarta \\ Hermawati05dewi@gmail.com
}

\begin{abstract}
ABSTRAK
Penelitian bertujuan untuk: 1) Menemukan resep otak-otak ikan gabus. 2) Menemukan formula otak-otak ikan gabus. 3) Mengetahui teknik olah pembuatan otakotak ikan gabus. 4) Mengetahui tingkat kesukaan panelis terhadap otak-otak ikan gabus. 5) Mengetahui kandungan gizi pada otak-otak ikan gabus dengan metode analisis proksimat. 6) Mengetahui perubahan kadar albumin pada otak-otak ikan gabus selama pengolahan. 7) Mengetahui porsi otak-otak ikan gabus untuk memenuhi kecukupan albumin. Analisis data yang digunakan adalah analisis data varian (ANAVA) dan LSD untuk mengetahui perubahan kandungan gizi pada otak-otak ikan gabus dan uji kesukaan pada otak-otak ikan gabus, selanjutnya perhitungan AKG dan diteruskan labeling gizi. Hasil penelitian menunjukkan : 1). Resep otak-otak ikan gabus yang digunakan adalah 120 gr daging ikan gabus, 70 gr es batu, 7 gr garam, 1 gr phosmix mp, 60 gr tepung tapioka, 20 gr tepung maizena, 7 gr modified starc ultra-k, 8 gr gula pasir, 20 gr bawang putih, 10 gr daun bawang. 2) Formula yang digunakan untuk membuat otak-otak ikan gabus yaitu bahan utama menggunakan $100 \%$ ikan gabus, bahan tambahan antara lain es batu 58,33\% dari bahan utama, phosmix MP 0,83\%, garam $5,83 \%$, tepung tapioka 50\%, tepung maizena $16,67 \%$, modified starch ultara-k 5,83\%, gula pasir $6,67 \%$, bawang putih $8,33 \%$ dan daun bawang $8,33 \%$ dari bahan utama. 3 ) Mengetahui teknik olah pembuatan otak-otak ikan gabus meliputi beberapa tahap, yaitu: seleksi bahan, penimbangan bahan, pemotongan bahan, penghalusan, pencampuran, pembentukan adonan dan pengukusan. Sedangkan penyelesaian akhir bisa memilih teknik olah kukus, teknik olah goreng dan teknik olah bakar. 4) Tingkat kesukaan panelis terhadap otak-otak ikan gabus yang didapatkan adalah otak-otak ikan gabus dengan penyelesaian akhir teknik olah goreng. 5) Kadar proksimat pada otak-otak ikan gabus adalah kadar air sebesar 47,11\%, kadar lemak sebesar 3,48\%, kadar protein sebesar 13,79\%, kadar abu sebesar 2,92\% dan kadar karbohidrat sebesar 32,69\%. 6) Perubahan kadar albumin total dari ikan gabus segar ke otak-otak ikan gabus mengalami penurunan sebesar 83,4633\%. Penggantian ikan tenggiri menjadi ikan gabus menyebabkan kadar albumin otak-otak ikan meningkat sebesar 40,7487 \%. 7) Otak-otak ikan gabus sebanyak 76 gram (1 bungkus otak-otak ikan gabus, isi 4 buah), memiliki kandungan lemak total 264,36 gram dapat mencukupi kebutuhan gizi usia umum sebesar 426,39\%. Kandungan protein totalnya 1048,43 gram dapat mencukupi AKG sebesar 1747,28 \%. Kandungan karbohidrat total 2484,94 gram dapat mencukupi AKG sebesar 828,31\%. Kandungan albumin total 182,76 g/dl dapat mencukupi AKG sebesar $3514,61 \%$.
\end{abstract}

Kata Kunci: Otak-Otak, Ikan Gabus, Albumin 


\begin{abstract}
This study aimed to: (1) find out grilled snakehead fish cake recipe; (2) find out grilled snakehead fish cake formula; (3) find out techniques in making grilled snakehead fish cake; (4) identify panelists' level of pleasure to grilled snakehead fish cake; (5) identify nutrients contain in grilled snakehead fish cake using proximate analysis; (6) identify albumin level changes in grilled snakehead fish cake during processing; and (7) find out grilled snakehead fish cake portion to meet albumin sufficiency. The data were analyzed using analysis of variant data (ANAVA) and LSD to identify the changes of nutrients content in grilled snakehead fish cake and pleasure test in grilled snakehead fish cake. Then, AKG calculation done and continued to nutrient labelling. The result of this study showed that : (1) recipe of grilled snakehead fish cake used were 120 grams of snakehead fish meat, 70 grams of ice cube, 7 grams of salt, 1 grams of phosmix mp, 60 grams of tapioca flour, 20 grams of cornstarch, 7 grams of modified starch ultra-k, 8 grams of sugar, 20 grams of garlic, 10 grams of leek; (2) formula used to make grilled snakehead fish cake were 100\% snakehead fish as the main ingredient, additional ingredients such as 58,33\% of ice cube of the main ingredients, 0,83\% of phosmix MP, 5,83\% of salt, 50\% of tapioca flour, 16,67\% of cornstarch, 5,83\% of modified starch ultara- $k$, 6,67\% of sugar, 8,33\% of garlic, and 8,33\% of leek of the main ingredients; (3) there were some steps in making grilled snakehead fish cake, such as selecting, weighing, cutting, smoothing, mixing ingredients, forming dough, and steaming. Besides, in the end of this process could be steaming, frying, or grilling; (4) frying technique had the highest level of pleasure for panelists; (5) proximate level of grilled snakehead fish cake were 47,11\% of water rate, 2,48\% of fat, 13,79\% of protein, $2,92 \%$ of ash, and 32,69\% of carbohydrate; (6) the changes of total albumin level in grilled snakehead fish cake had decreased about 83,4633\%. The change of Spanish mackerel to snakehead fish caused the albumin rate increased about 40,7487\%; and (7) 76 grams of grilled snakehead fish cake (1 pack of grilled snakehead fish cake consists of 4 pieces), it had 264,36 grams of fat which could fulfil nutrient need for general age for about 426,39\%; 1048,43 grams of total protein which could fulfill AKG for about 1747,28\%; 2484,94 grams of total carbohydrate which could fulfil AKG for about $828,31 \% ; 182,76 \mathrm{~g} / \mathrm{dl}$ of total albumin which could meet $A K G$ for about 3514,61\%.
\end{abstract}

Keyword: grilled snakehead fish cake, snakehead fish, albumin

\section{PENDAHULUAN}

Indonesia merupakan negara maritim yang terdiri dari $2 / 3$ bagian air dan laut, selebihnya daratan terdiri dari 13.000 pulau besar dan kecil merupakan negara yang kaya dan sangat melimpah, lautnya kaya raya akan sumber daya alam. Luas perikanan laut Indonesia diperkirakan sebesar 5,8 juta $\mathrm{km}^{2}$ dengan garis pantai terpanjang di dunia sebesar $81.000 \mathrm{~km}$ dan gugusan pulau-pulau 


\section{Sabbhata Yatra}

Jurnal Pariwisata dan Budaya

Volume 1 Nomor 1 Juli 2021

sebanyak 17.508, memiliki potensi

Makanan, 2005 : 10). Selain komposisi

ikan yang diperkirakan terdapat

sebanyak 6,26 juta ton per tahun yang

dikelola secara lestari dan 4,4 juta ton

dapat ditangkap di perairan Indonesia

dan 1,86 juta ton diperoleh dari

perairan ZEEI (Departemen Kelautan

dan Perikanan, 2008:03).

Standard yang ditentukan oleh

FAO (Food and Agriculture

Organization of the United Nations,

Badan PBB yang menangani masalah pertanian dan pangan) adalah $31 \mathrm{~kg}$ per kapita per tahun. Sedangkan konsumsi ikan nasional di akhir tahun 2010 mencapai 30,47 kg per kapita per tahun, meningkat dibandingkan pada 2009 yang 29,08 kg per kapita per tahun. Namun jika dibandingkan dengan negara maju lainnya kita masih jauh tertinggal. Sebagai contoh, konsumsi ikan di Jepang $110 \mathrm{~kg}$ per kapita per tahun, Korea Selatan $85 \mathrm{~kg}$ per kapita per tahun, dan Malaysia 45 $\mathrm{kg}$ per kapita per tahun. (Ridwan Kharis, 2011)

Ikan gabus memiliki manfaat yang tinggi untuk kesehatan manusia. Ikan yang memiliki zat gizi seperti protein (25,2 gr), lemak (1 gr), kalsium (90 gr), fosfor (192 mg), besi (25 mg) yang lebih tinggi dibandingkan jenis ikan air tawar lainya (Daftar Komposisi Bahan

gizi yang dimiliki ikan gabus yang telah disebutkan, ikan ini juga memiliki gizi unggulan yaitu albumin. Albumin merupakan jenis protein terbanyak didalam plasma yang mencapai kadar 60\%. Albumin bermanfaat dalam pertumbuhan jaringan sel baru. Pembentukan jaringan tubuh yang dibutuhkan pada saat pertumbuhan (bayi, kanak-kanak, remaja dan ibu hamil) dan mempercepat penyembuhan jaringan tubuh misalnya sesudah operasi, luka bakar dan saat sakit. (Florentinus Nurtitus, 2005 : 03). Sebenarnya albumin dapat diperoleh dari sumber makanan lain, seperti ikan gabus, lele, telur dan susu.

Otak-otak ikan gabus pada prinsipnya mengacu pada otak-otak ikan. Otak-otak ikan merupakan sejenis makanan yang terbuat dari daging ikan yang dibungkus dengan daun pisang kemudian dibakar menggunakan api arang kayu ataupun sabut kelapa. Otak-otak ikan biasanya terbuat dari daging ikan tenggiri, santan, sagu, bumbu dan gula. Ada pula otak-otak yang tidak menambahkan santan, namun menggunakan air es atau es batu. Otakotak ikan biasanya dibuat dengan 
teknik olah dibakar dan digoreng. Meskipun begitu, otak-otak ikan pada umumnya lebih terkenal dengan teknik olah dibakar.

Peneliti mencoba membandingkan teknik olah untuk otak-otak ikan gabus. Teknik olah yang digunakan meliputi kukus, goreng dan bakar. Meskipun teknik olah yang diterapkan sama, namun bedanya adalah semua adonan dibungkus terlebih dahulu menggunakan daun pisang, kemudian dikukus. Penelitian ini dilakukan guna memperoleh informasi tentang kandungan albumin yang terdapat dalam ikan gabus, ditinjau dari analisis kandungan albumin pada otak-otak ikan gabus.

\section{BAHAN DAN METODE}

\section{Bahan dan Alat}

Bahan yang digunakan dalam pembuatan otak-otak ikan gabus adalah ikan gabus yang didapat dari pasar tradisional. Ikan gabus yang digunakan dalam penelitian ini menggunakan daging ikan gabus sebesar 120 gr, selain daging ikan gabus juga menggunakan es batu sebanyak $70 \mathrm{gr}$, tepung tapioka $60 \mathrm{gr}$, tepung maizena 20 gr, gula pasir 8 gr, garam 7 gr, bawang putih 10 gr, daun bawang 10 gr. Selain itu menggunakan bahan kimia yaitu phosmix MP 1 gr,
Modified SUB 7 gr. Bahan kimia yang digunakan untuk analisis kadar protein antara lain : $\mathrm{Na}_{2} \mathrm{SO}_{4}, \mathrm{CuSO}_{4}$, asam sulfat, $\mathrm{NaOH}, \mathrm{HCl}$, asam borat. Bahan kimia yang digunakan untuk analisis kadar lemak antara lain petroleum eter. Bahan kimia yang digunakan untuk analisis kadar albumin antara lain aquades, lowry A, lowry B, lowry C, lowry D dan lowry E.

Alat yang digunakan food processor merk Philips, kompor merk Rinai, Steamer alumunium, Pan, cutting board, knife, spoon, bowl, measuring scale, sealer. Alat yang digunakan dalam analisi kadar air adalah neraca analitis atau neraca elektronik, botol timbang, mortar porselin, penjepit, eksikator, dan oven. Alat yang digunakan dalam analisis kadar abu antara lain desikator, Bunsen, cawan porselen, tanur, dan timbangan elektronik. Alat yang digunakan dalam analisis kadar protein adalah Erlenmeyer, pipet, beaker glass, buret, statif, gelas ukur, timbangan elektronik, labu ukur, blender dan corong. Alat yang digunakan dalam analisis kadar lemak yaitu thimble, tabung ekstraksi mikro Soxhlet, alat distilasi mikro Soxhlet, labu godog, water bath, oven, neraca analitis, dan desikator. Alat uji analisis kadar 


\section{Sabbhata Yatra}

Jurnal Pariwisata dan Budaya

Volume 1 Nomor 1 Juli 2021

albumin meliputi spektrometer, tabung

reaksi, timbangan elektronik.

\section{METODE}

Penelitian dilakukan dalam dua tahap, yaitu tahap 1 Analisis Proksimat yang meliputi analisis kadar air dengan metode oven vaccum, analisis kadar abu (metode penetapan total abu), analisa kadar lemak (metode Soxhlet), analisa protein (metode Kjeldahl), analisis karbohidrat (metode by different) dan tahap ke 2 yaitu analisis albumin (metode Lowry).

\section{Analisis kadar air}

Metode yang digunakan dengan Thermografimetri berdasarkan metode Anton Apriyantono (1989). Prosedur melakukan analisis kadar air adalah sebagai berikut: 1. Sampel dihaluskan kemudian ditimbang 5 gr sampel (cawan dipanaskan pada suhu $105^{\circ} \mathrm{C}$, dinginkan dan ditimbang), 2. Dimasukkan dalam cawan tertutup, kemudian dioven, setelah dioven dikeringkan (tutup aliran vakum pompa), dinginkan dalam desikator, 3 . Panaskan kembali hingga mendapatkan berat yang tetap, timbang dan dihitung.

Perhitungan kadar air bahan:

Berat botol timbang kosong $=\mathrm{a}$

Berat botol timbang + sampel $=b$

Berat konstan $=\mathrm{c}$

Berat bahan basah $=\mathrm{d}=\mathrm{b}-\mathrm{a}$
Berat bahan kering $=\mathrm{e}=\mathrm{c}-\mathrm{a}$

Berat air dalam bahan yang diuapkan $=$ $\mathrm{f}=\mathrm{d}-\mathrm{e}$

Kadar air bahan $(($ web basis $)=$ berat basah) $=\frac{f}{d} \quad 100 \%$

Kadar air bahan ((dry basis) $=$ berat kering $)=\frac{f}{e} \quad 100 \%$

\section{Analisis kadar protein}

Metode yang digunakan dalam analisis kadar protein menggunakan metode Kjedahl-mikro. Pada metode ini protein ditetapkan berdasarkan oksidasi bahan-bahan berkarbon dan konversi nitrogen menjadi amonia. Selanjutnya amonia berkonversi dengan kelebihan asam membentuk amunium sulfur, larutan dibuat menjadi basa dan amonia diuapkan untuk kemudian diserap dalam larutan asam borat. Nitrogen yang terkandung dalam larutan dapat ditentukan jumlahnya dengan titrasi menggunakan $\mathrm{HCl} 0,02 \mathrm{~N}$. (Anton Apriyantono, 1989). Cara perhitungan analisis kadar protein :

Perhitungan jumlah total $\mathrm{N}$ Jumlah $\mathrm{N}$ Total $=$

$(m l-m l$ blangko) $x$ normalitas $x 14,007 \times 100 \%$ Berat sampel /l

$\%$ Protein $=\% \quad \mathrm{~N} \quad \mathrm{x}$ factor konversi 
bakar dalam tanur pengabuan (tahap I

Metode yang digunakan untuk analisis kadar lemak adalah metode Soxhlet metode Anton Apriyantono (1989). Prosedur yang digunakan adalah sebagai berikut: sampel dihaluskan dan ditimbang 1-2 gr, kemudian dimasukkan dalam tabung ekstraksi Soxhlet dalam timbel dan dioven. Didestilasi selama 4 jam (tambahkan petroleum ether) kemudian uapkan diatas water bath, keringkan dalam oven dengan suhu $100^{\circ} \mathrm{C}$ sampai berat konstan. Timbang dan dihitung.

Perhitungan :

$\%$ lemak $=\frac{\text { berat ekstrak }}{\text { berat sampel }} \times 100 \%$

\section{Analisis kadar abu}

Analisis kadar abu ditetapkan dengan metode penetapan total abu. Prinsip dari metode ini yaitu abu dalam bahan pangan ditetapkan dengan menimbang sisa mineral hasil pembakaran bahan organic pada suhu sekitar $550^{\circ} \mathrm{C}$.

Prosedur pengujian kadar abu adalah sebagai berikut: Sampel dihaluskan dan ditimbang 3-5 gr, kemudian dimasukkan dalam cawan pengabuan (panaskan cawan, dinginkan dan ditimbang). Setelah itu pada suhu $400^{\circ} \mathrm{C}$ ), bakar lagi tahap II (pada suhu $500^{\circ} \mathrm{C}$ ), dinnginkan dalam desikator, timbang dan dihitung. Cara perhitungan kadar abu adalah sebagai berikut :

Kadar $a b u=\frac{\text { berat } a b u(g r)}{\text { berat sampel }(g r)} \times 100 \%$

\section{Analisis kadar karbohidrat}

Pada umumnya, analisis karbohidrat dilakukan secara tidak langsung melalui perhitungan metode ini disebut carbohidrat by difference atau karbohidrat melalui selisih. Cara perhitungan analisis karbohidrat :

$\%$ karbohidrat $=100 \%-($ kadar lemak

+ kadar protein + kadar abu + kadar air)

\section{Analisis kadar albumin}

Metode yang digunakan adalah metode Lowry. Metode ini merupakan pengembangan dan penggabungan dari metode Biuret dan metode Folin yang dilakukan oleh Lowry kurang lebih 45 tahun yang lalu. Adanya inti aromatis pada asam amino tirosin, triptofan, dan fenilalanin akan mereduksi kedua macam perekasi.

Lowry A (asam fosfomolibdat : asam fosfotungsat 1:1) menjadi molibdenum yang berwarna biru yang 


\section{Sabbhata Yatra}

Jurnal Pariwisata dan Budaya

Volume 1 Nomor 1 Juli 2021

selanjutnya ditambahkan perekasi

Lowry B (CuSO $4+\mathrm{Na} 2 \mathrm{CO} 32 \%$

dalam $\mathrm{NaOH} 0,1 \mathrm{~N}+\mathrm{K}$ Na-tatrat 2\%)

sehingga menghasilkan warna yang

lebih stabil dan dapat diukur absorbansinya pada $\lambda 600 \mathrm{~nm}$. Metode ini lebih senditif daripada metode Biuret.

\section{PEMBAHASAN}

\section{Pra-eksperimen}

Untuk mendapatkan formula resep otak-otak ikan gabus yang tepat, perlu melalui beberapa kali eksperimen. Sebelumnya telah menggunakan 2 resep dan hasil yang diperoleh belum bisa maksimal. Resep yang pertama dan kedua memiliki kelebihan yang hampir sama, yaitu rasa gurih (berasal dari santan). Kelebihan dari penggunaan santan untuk menghasilkan rasa yang gurih, ternyata menjadi kekurangan karena masa simpan otak-otak ikan gabus menjadi pendek/tidak tahan lama.

Penggunaan bahan-bahan pada pembuatan otak-otak ikan gabus akan mempengaruhi rasa, aroma dan tekstur. Bahan-bahan pada resep I dan II belum dapat menghasilkan criteria produk otak-otak yang sesuai. Maka dari itu, perlu penggantian bahan maupun penambahan bahan lain untuk mendapatkan criteria produk otak-otak ikan yang baik.

2. Formula Otak-Otak Ikan Gabus

a. Tahap awal

Pembuatan otak-otak ikan gabus ini menggunakan bahan baku daging ikan gabus segar. Penggunaan daging ikan gabus yang masih segar ini bertujuan agar otak-otak ikan gabus memiliki aroma yang tidak busuk. Dalam pembuatan otak-otak ikan gabus ini perlakuan awal yang dilakukan adalah membersihkan ikan gabus kemudian memisahkan antara daging dan tulangnya (fillet). Setelah dibersihkan kemudian dicuci terlebih dahulu sebelum dihaluskan.

b. Proses pembuatan

Pembuatan otak-otak ikan gabus menggunakan fillet. Prosedur pembuatanya yaitu daging ikan gabus dihaluskan dengan menggunakan food processor sampai setengah halus kemudian ditambahkan $1 / 2$ bagian es batu dan dihaluskan kembali sampai halus, setelah itu ditambahkan sisa es batu dan bahan-bahan lain sedikit demi sedikit sampai semua tercampur rata dan yang terakhir adalah daun bawang.

Setelah proses pencampuran dan penghalusan bahan, kemudian adonan dibungkus dengan daun pisang dan selanjutnya dikukus selama 20 menit. 


\section{Sabbhata Yatra}

Jurnal Pariwisata dan Budaya

Volume 1 Nomor 1 Juli 2021

Proses pengukusan ini bertujuan agar adonan matang dan otak-otak ikan gabus terbentuk dengan baik. Setelah proses pengukusan biarkan otak-otak ikan gabus dingin sebelum dikemas.

c. Tahap akhir

Setelah memperoleh formula otak-otak ikan gabus, maka dilanjutkan dengan perlakuan pada teknik olah. Teknik olah yang digunakan meliputi teknik olah kukus, teknik olah goreng dan teknik olah bakar. Alasan pemilihan teknik olah tersebut karena selama ini otak-otak ikan hanya menggunakan teknik olah yang sederhana, yaitu pada umumnya dibakar. Proses yang sederhana dengan adonan mentah dibungkus daun pisang kemudian dibakar. Proses seperti ini tidak memiliki daya simpan yang lama.

Penambahan variasi teknik olah pada otak-otak ikan gabus akan memberikan rasa yang berbeda dan tingkat kekenyalan yang berbeda pula. Perbedaan rasa pada otak-otak ikan gabus dengan teknik pengolahan yang digunakan karena media pemansan yang digunakan member aroma dan rasa yang berbeda. Untuk teknik olah kukus akan beraroma daun pisang dan tekstur sedikit empuk, untuk teknik olah goreng memiliki rasa gurih karena minyak goreng (lemak) memiliki ciri rasa gurih dan tekstur kenyal dan empuk, selanjutnya untuk teknik olah bakar memiliki aroma yang khas dari bara api yang digunakan dan rasa gurih sedangkan tekstur yang dihasilkan empuk dan sedikit kenyal.

3. Uji kesukaan produk otak-otak ikan gabus

Tingkat kesukaan konsumen terhadap keseluruhan, warna, aroma, rasa dan tekstur ketiga produk otakotak ikan gabus sebagai berikut :

a. Keseluruhan

Berdasarkan uji kesukaan didapatkan bahwa kategori penampilan secara keseluruhan mulai darai warna, aroma, rasa dan tekstur terbaik yang disukai pertama oleh panelis adalah otak-otak ikan gabus dengan perlakuan teknik olah kedua, yaitu otak-otak ikan gabus dengan teknik olah digoreng, dengan nilai rerata 3,8667 . Selanjutnya yang disukai kedua adalah perlakuan teknik olah yang pertama yaitu dengan teknik olah dikukus dengan nilai rerata 3,2333 dan yang terakhir adalah otakotak ikan gabus dengan teknik olah ketiga yaitu di bakar dengan nilai rerata 3,1667. Dari rerata diatas, otakotak ikan gabus dengan teknik olah kedua disukai karena dari segi penampilan yang lebih menarik, adapun komentar panelis yang 


\section{Sabbhata Yatra}

Jurnal Pariwisata dan Budaya

Volume 1 Nomor 1 Juli 2021

mengatakan bahwa produk sudah layak. Dilihat dari warna otak-otak dengan teknik olah kedua ini lebih menarik, rasa ikan yang tidak terlalu amis dan aroma ikan tidak terlalu tajam.

b. Warna

Warna sangat berperan penting bagi suatu produk makanan, karena warna akan memberikan penilaian tersendiri bagi konsumen. Selain kesan dari produk, warna makanan juga akan membangkitkan selera makan.

Berdasarkan uji indrawi oleh 30 panelis dengan 3 sampel untuk indicator warna, urutan sampel terbaik dari hasil uji indrawi adalah sebagai berikut : otak-otak ikan gabus dengan perlakuan teknik olah kedua, yaitu otak-otak ikan gabus dengan teknik olah digoreng, dengan nilai rerata 3,8667. Selanjutnya perlakuan teknik olah yang ketiga yaitu dengan teknik olah dibakar dengan nilai rerata 3,5667 dan yang terakhir adalah otak-otak ikan gabus dengan teknik olah pertama yaitu dikukus dengan nilai rerata 3,3000. Adanya warna yang ditimbulkan dari ketiga produk tersebut karena proses pemanasan dan media yang digunakan. Untuk yang pertama dengan menggunakan media minyak goreng menghasilkan warna coklat keemasan. Yang kedua dengan media dibungkus daun pisang kemudian dibakar, menghasilkan warna putih tulang namun sembam karena panas bara yang di gunakan. Selanjutnya, warna yang dihasilkan oleh teknik olah dikukus adaalh putih tulang agak kecoklatan karena efek daun pisang yang terkena uap panas.

c. Aroma

Berdasarkan uji kesukaan didapatkan bahwa aroma yang disukai oleh panelis adalah otak-otak ikan gabus dengan perlakuan teknik olah digoreng, dengan nilai rerata 3,5333. Selanjutnya perlakuan teknik olah yang disukai kedua yaitu dengan teknik olah dibakar dengan nilai rerata 3,0333 dan yang terakhir adalah otakotak ikan gabus dengan teknik olah di bakar dengan nilai rerata 2,9333.

d. Rasa

Berdasarkan uji kesukaan didapatkan bahwa rasa yang disukai oleh panelis adalah otak-otak ikan gabus dengan perlakuan teknik olah kedua, yaitu otak-otak ikan gabus dengan teknik olah dikukus, dengan nilai rerata 3,9000. Selanjutnya perlakuan teknik olah yang disukai kedua yaitu dengan teknik olah digoreng dengan nilai rerata 3,5000 dan yang terakhir adalah otak-otak 


\section{Sabbhata Yatra}

Jurnal Pariwisata dan Budaya

Volume 1 Nomor 1 Juli 2021

ikan gabus dengan teknik olah di bakar

dengan nilai rerata 2,8667 .

Rasa yang ditimbulkan berbedabeda dikarenakan proses/teknik pengolahan yang dilakukan. Untuk proses pemanasan/pengolahan dengan dikukus(penguapan suhu tinggi) akan menghasilkan rasa ikan gabus yang masih sangat melekat. Selanjutnya untuk proses pengolahan goreng, akan menghasilkan rasa gurih dan rasa ikan gabus mulai berkurang, selanjtnya untuk teknik olah bakar, menghasilkan rasa ikan dan bahan-bahan lain masih terasa tajam, hal ini dikarenakan pematangan bahan-bahan yang masih kurang maksimal.

e. Tekstur

Berdasarkan uji kesukaan didapatkan bahwa tekstur yang disukai pertama oleh panelis adalah otak-otak ikan gabus dengan perlakuan teknik olah kedua, yaitu otak-otak ikan gabus dengan teknik olah digoreng, dengan nilai rerata 3,6333. Selanjutnya perlakuan teknik olah yang disukai kedua yaitu dengan teknik olah dibakar dengan nilai rerata 3,5667 dan yang terakhir adalah otak-otak ikan gabus dengan teknik olah dikukus dengan nilai rerata 2,0667.

4. Kandungan Proksimat pada otakotak ikan gabus
Dari hasil analisis proksimat pada otak-otak ikan gabus kandungan gizi terbesar adalah kadar air dengan nilai rerata 47,1115\% dan kandungan gizi paling rendah adalah albumin dengan nilai rerata 2,4047\%. Berdasarkan hasil uji laboratorium diatas, diperoleh hasil pembahasan analisis proksimat pada otak-otak ikan gabus :

\section{a. Kadar Air}

Kandungan air yang terdapat dalam otak-otak ikan gabus adalah dengan rarata 47,11\%. Hal tersebut menunjukkan bahwa otak-otak ikan gabus mempunyai kadar air yang mendekati standar yang telah ditetapkan, yaitu pada SNI 01-38201995, kadar air yang ditetapkan pada sosis ikan sebesar maksimum 67\%. Kadar air pada otak-otak ikan gabus ini tergolong cukup tinggi, hal ini dikarenakan penambahan bahan yaitu phosmix MP yang berfungsi untuk mengikat air dalam bahan pangan. Kadar air sangat berpengaruh terhadap mutu bahan pangan, hal ini merupakan salah satu penyebab dimana air sering dikeluarkan atau dikurangi dengan cara penguapan atau pengentalan dan penyaringan (F.G. Winarno, 1984). Pengurangan air ini bertujuan untuk mengawetkan juga untuk mengurangi 


\section{Sabbhata Yatra}

Jurnal Pariwisata dan Budaya

Volume 1 Nomor 1 Juli 2021

berat bahan dari suatu produk pangan, sehingga akan lebih mudah dalam pengemasannya.

Air adalah komponen yang paling penting dari suatu produk pangan, adanya air yang terkandung dari suatu produk pangan akan mempengaruhi penampilan, rasa dan tekstur. Semua bahan makanan mengandung air yang berbeda-beda. Kandungan air ini akan mempengaruhi kesegaran produk makanan.

Adanya standar yang ditetapkan untuk jumlah air yang terkandung dari suatu produk makanan, hal ini mencegah kerusakan kandungan gizi pada makanan tersebut. Pada pembuatan otak-otak ikan gabus ini, ditambahkan beberapa bahan pengental yang berfungsi mengentalkan adonan juga mengurangi kadar air pada adonan. Penambahan tepung tapioka dan maizena ini juga akan membentuk tekstur kenyal pada otak-otak ikan gabus. Kadar air yang terkandung pada suatu makanan akan mempengaruhi tingkat kekenyalan atau tekstur ddari makanan tersebut. Jika semakin tinggi kadar airnya, maka akan semakin lunak tekstur dari makanan tersebut. Namun sebaliknya, apabila semakin rendah kadar air dalam makanan

tersebut semaki kenyal pula tekstur dari makanan itu.

b. Kadar Abu

Dari hasil uji Laboratorium, kadar abu yang dimiliki otak-otak ikan gabus ini memiliki rerata 2,9181\%. Kadar abu ini merupakan jumlah total bahan yang digunakan untuk pembuatan otak-otak ikan gabus. Kadar abu berasal dari semua bahan yang digunakan untuk membuat otakotak ikan.

Ketentuan mutu otak-otak ikan menurut SNI 01-2891-1992 butir 6.1, menunjukkan bahwa otak-otak ikan, memiliki kadar abu $<3 \%$. Dari hasil uji Laboratorium otak-otak ikan gabus memiliki kadar abu kurang dari 3\%.

c. Kadar Lemak

Dari hasil uji Laboratorium, kadar lemak yang dimiliki otak-otak ikan gabus ini memiliki rerata 3,4784\%. Kadar lemak ini merupakan jumlah lemak yang terkandung dalam bahan-bahan pembuatan otak-otak ikan gabus, seperti ikan gabus, tepung tapioka, bawang putih, daun bawang dan minyak goring

Ketentuan SNI 01-2891-1992 butir 8.2 tentang oak-otak ikan, menunjukkan bahwa otak-otak ikan, memiliki kadar lemak maksimal 2,43\%. Dari hasil uji Laboratorium 


\section{Sabbhata Yatra}

Jurnal Pariwisata dan Budaya

Volume 1 Nomor 1 Juli 2021

otak-otak ikan gabus memiliki kadar

lemak lebih dari 2,43\%, hal ini karena

otak-otak ikan gabus yang diuji adalah

otak-otak ikan gabus goreng,

kandungan minyaknya lebih tinggi

dibandingkan SNI.

d. Kadar Protein

Protein dapat mengalami kerusakan oleh pengaruh panas, reaksi kimia dengan asam, atau basa, goncangan dan lain-lainnya. Pengaruh tersebut dalam bahan makanan dikenal terjadinya penggumpalan atau pengerutan (F. G. Winarno. 1984 : 46).

Dari hasil uji Laboratorium, kadar protein yang dimiliki otak-otak ikan gabus ini memiliki rerata 13,7952\%. Ketentuan SNI 01-28911992 butir 7.1 tentang otak-otak ikan, menunjukkan bahwa suatu produk makanan (otak-otak ikan), memiliki kadar protein minimal 10,5\%. Dari hasil uji Laboratorium otak-otak ikan gabus memiliki kadar protein lebih dari 10,5\%. Protein terbesar berasal dari bahan utama, yaitu daging ikan gabus dan dari bahan-bahan yang digunakan untuk membuat otak-otak ikan gabus, yaitu tepung tapioka, tepung maizena, bawang putih dan daun bawang (lihat tabel di lembar lampiran).

e. Kadar Karbohidrat
Dari hasil uji Laboratorium, kadar karbohidrat yang dimiliki otakotak ikan gabus ini memiliki rerata 30,5431\%. Ketentuan SNI 01-38911992 tentang otak-otak ikan, menunjukkan bahwa otak-otak ikan, memiliki kadar karbohidrat minimal 21,8\%. Dari hasil uji Laboratorium otak-otak ikan gabus memiliki kadar karbohidrat lebih dari 21,8\%. Karbohidrat berasal dari semua bahan yang digunakan dalam pembuatan otak-otak ikan gabus, yaitu : ikan gabus, tepung tapioka, tepung maizena, gula pasir, bawang putih dan daun bawang. (lihat lampiran pada lembar lampiran).

5. Perubahan Kadar Albumin OtakOtak Ikan Gabus Selama Pengolahan

Albumin merupakan jenis protein terbanyak di dalam plasma yang mencapai kadar 60 persen. Nilai normal albumin didalam darah sekitarb 3,5-5 g/dl. Protein yang larut dalam air dan mengendap pada pemanasan itu merupakan salah satu konstituen utama tubuh. Albumin termasuk dalam protein glubolar yaitu protein yang berbentuk bola. Protein ini larut dalam garam dan asam encer, mudah berubah dibawah pengaruh suhu, konsentrasi garam serta mudah mengalami 


\section{Sabbhata Yatra}

Jurnal Pariwisata dan Budaya

Volume 1 Nomor 1 Juli 2021

denaturasi.(Sunita Almatsier , 2004 : 86).

Dari nilai komposisi bahan makanan dikatakan bahwa kandungan protein dalam ikan gabus ternyata paling tinggi, yaitu $25 \%$ dan menurut Johanes Carvallo (1998), kadar albumin pada ikan gabus segar sebesar $6,2 \%$, dengan kadar lemak rendah. (Florentinus Nurtitus, 2005)

Pada ikan tenggiri albumin termasuk dalam komponen protein secara umum. Protein pada ikan tenggiri dalam 100 gram daging ikan tenggiri adalah 18,5 gram. (http://repository.ipb.ac.id)

Berdasarkan hasil pengujian maka diperoleh urutan nilai rerata dari nilai terbesar ke nilai terkecil yaitu ikan gabus segar dengan nilai 5,6087, otak-otak ikan gabus dengan nilai 2,4047 dan otak-otak ikan tenggiri (produk acuan) dengan nilai 1,4250. Berdasarkan Tabel 26, penurunan kadar albumin pada ikan gabus segar dan otak-otak ikan gabus mengalami penurunan yang sangat drastis. Untuk otak-otak ikan gabus dan otak-otak ikan tenggiri menggalami penurunan yang tidak begitu signifikan.

Perubahan kadar albumin total selama proses pengolahan otak-otak ikan gabus dari analisa kadar air dan

kadar albumin total, diawali dengan penyetaraan kadar air yang sama, hasil kadar air ikan gabus segar ulangan I sebesar 79,6133 \%. Dari hasil perhitungan, perubahan kadar albumin total dari ikan gabus segar ke otak-otak ikan gabus bernilai negatif (-), hal ini menunjukkan terjadinya penurunan kadar albumin pada ikan gabus segar ke otak-otak ikan gabus sebesar $83,4633 \%$. Kemudian perubahan kadar albumin total dari otak-otak ikan tenggiri (produk acuan) ke otak-otak ikan gabus berharga positif $(+)$, hal ini menunjukkan terjadinya peningkatan kadar albumin total pada otak-otak ikan gabus sebesar 40,7487 \%. Hal ini dapat disimpulkan bahwa otak-otak ikan gabus memiliki kadar albumin total lebih tinggi dari pada otak-otak ikan tenggiri (produk acuan).

Untuk penurunan kadar albumin total dari ikan gabus segar ke otak-otak ikan gabus disebabkan karena adanya proses pemanasan yaitu saat proses pengolahan dikukus dan digoreng. Pada proses pengolahan ini albumin total akan mengalami koagulasi bila dipanaskan. Sedangkan untuk kadar albumin otak-otak ikan tenggiri (produk acuan) ke otak-otak ikan gabus mengalami peningkatan, hal ini disebabkan adanya perbedaan bahan 


\section{Sabbhata Yatra}

Jurnal Pariwisata dan Budaya

Volume 1 Nomor 1 Juli 2021

baku yang digunakan, berbeda pula

kadar albumin total yang dimiliki oleh

bahan baku (daging ikan).

6. Perhitungan Porsi Otak-Otak Ikan

Gabus Untuk Memenuhi Kebutuhan

Albumin

Sasaran konsumen otak-otak ikan gabus adalah masyarakat usia umum. Kebutuhan energi yang dibutuhkan untuk usia umum adalah 2000 kalori.

Dari hasil perhitungan yang telah dilakukan, maka takaran saji otak-otak ikan gabus sebanyak 76 gram per porsi atau 1 bungkus otak-otak ikan gabus. Konsumsi sebanyak 76 gram otak-otak ikan gabus, memiliki kandungan lemak total 0,66 gram dapat mencukupi kebutuhan gizi usia umum sebesar 1,1 $\%$. Kandungan protein totalnya 2,62 gram dapat mencukupi kebutuhan gizi usia umum sebesar 4,4\%. Kandungan karbohidrat total 6,21 gram dapat mencukupi kebutuhan gizi usia umum sebesar 2,1 \%. Kandungan albumin total $0,46 \mathrm{~g} / \mathrm{dl}$ dapat mencukupi kebutuhan gizi usia umum sebesar 8,8 $\%$.

Sebagai lauk pauk setiap satu takaran otak-otak ikan gabus dapat mencukupi kebutuhan albumin total usia umum sebesar $48 \%$, yaitu dalam satu hari disarankan untuk

mengkonsumsi sebanyak 1 bungkus (76 gr). Angka tersebut masih belum mencukupi kebutuhan albumin total yang dianjurkan, sebab otak-otak ikan gabus digunakan untuk makanan selingan sehingga untuk menambah kadar albumin dapat mengkonsumsi makanan dari bahan makanan lain yang mengandung albumin seperti putih telur maupun ikan lele.

\section{PENUTUP}

Berdasarkan eksperimen yang telah dilakukan, maka diperoleh kesimpulan sebagai berikut :

1. Resep otak-otak ikan gabus yang digunakan adalah 120 gr daging ikan gabus, 70 gr es batu, 7 gr garam, 1 gr phosmix mp, 60 gr tepung tapioka, 20 gr tepung maizena, 7 gr modified starc ultra-k, 8 gr gula pasir, 20 gr bawang putih, 10 gr daun bawang.

2. Formula yang digunakan untuk membuat otak-otak ikan gabus yaitu bahan utama menggunakan 100\% ikan gabus, bahan tambahan antara lain es batu 58,33\% dari bahan utama, phosmix MP 0,83\%, garam $5,83 \%$, tepung tapioka $50 \%$, tepung maizena $16,67 \%$, modified starch ultara-k 5,83\%, gula pasir $6,67 \%$, 


\section{Sabbhata Yatra}

Jurnal Pariwisata dan Budaya

Volume 1 Nomor 1 Juli 2021

bawang putih $8,33 \%$ dan daun bawang $8,33 \%$ dari bahan utama.

3. Mengetahui teknik olah pembuatan otak-otak ikan gabus meliputi beberapa tahap, yaitu: seleksi bahan, penimbangan bahan, pemotongan bahan, penghalusan, pencampuran, pembentukan adonan dan pengukusan. Sedangkan penyelesaian akhir bisa memilih teknik olah kukus, teknik olah goreng dan teknik olah bakar.

4. Tingkat kesukaan panelis terhadap otak-otak ikan gabus yang didapatkan adalah otak-otak ikan gabus dengan penyelesaian akhir teknik olah goreng.

5. Kadar proksimat pada otak-otak ikan gabus adalah kadar air sebesar 47,11\%, kadar lemak sebesar $3,48 \%$, kadar protein sebesar 13,79\%, kadar abu sebesar 2,92\% dan kadar karbohidrat sebesar $32,69 \%$.

6. Perubahan kadar albumin total dari ikan gabus segar ke otak-otak ikan gabus mengalami penurunan sebesar 83,4633\%. Penggantian ikan tenggiri menjadi ikan gabus menyebabkan kadar albumin otakotak ikan meningkat sebesar $40,7487 \%$. 


\section{Sabbhata Yatra}

Jurnal Pariwisata dan Budaya

Volume 1 Nomor 1 Juli 2021

Ratnaningsih, Nani. (2005). Analisis Gizi Dalam Pengolahan. Jobsheet. Yogyakarta : Pendidikan Teknik Boga dan Busana. UNY

Sudarmadji dkk. (1997). Prosedur Analisa untuk Bahan Makanan dan Pertanian FPT UGM. Yogyakarta: Liberty.

Sudarmadji, Slamet, Suhardi dan Bambang Haryono. (1989). Analisis Bahan Makanan dan Pertanian. Yogyakarta : Liberti Yogyakarta

Sukarno. (2008). Analisis Gizi Proksimat.

http://Sukarno.web.ugm.ac.id/analisi sproksimat/10 Maret 2021.

Suyitno. (1990). Bahan-Bahan Pengemasan.Yogyakarta : Pusat Antar UniversitasGadjah Mada.

Winarno, F.G. (1984). Kimia Pangan dan Gizi. Jakarta: PT. Gramedia PustakaUtama.

Winarno, F.G. (1993). Kerusakan Bahan Pangan. Jakarta: PT. Gramedia PustakaUtama.

Winarno, F.G. (1993). Pengantar Teknologi Pangan. Jakarta: PT. Gramedia Pustaka Utama.Robert S. Harris dan Endel Karmas. (1989). Evaluasi Gizi Pada Pengolahan Bahan Pangan. Bandung : ITB Bandung. 